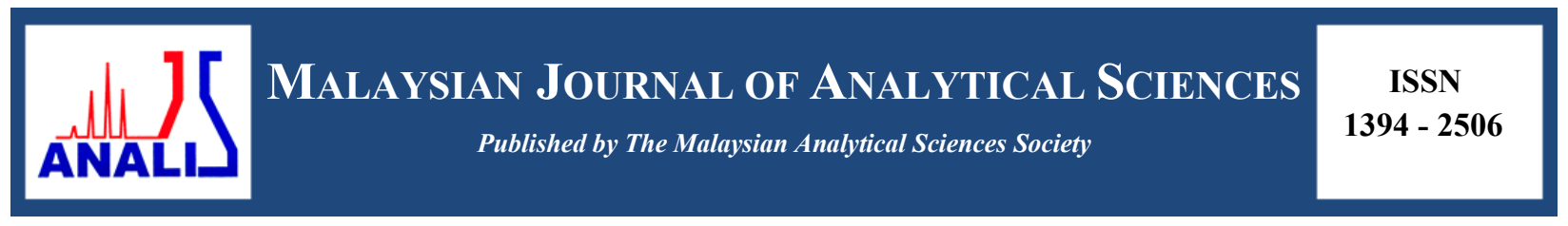

\title{
IN VITRO NITRIC OXIDE SCAVENGING AND ANTI INFLAMMATORY ACTIVITIES OF DIFFERENT SOLVENT EXTRACTS OF VARIOUS PARTS OF Musa paradisiaca
}

\section{(Aktiviti Pemerangkapan Nitrik Oksida dan Anti-Radang Secara In Vitro oleh Ekstrak Pelarut Berbeza dari Pelbagai Bahagian Musa paradisiaca)}

\author{
U.S Mahadeva Rao ${ }^{1 *}$, Bashir Ado Ahmad ${ }^{1}$, Khamsah Suryati Mohd $d^{2,3}$ \\ ${ }^{1}$ Faculty of Medicine, \\ Universiti Sultan Zainal Abidin, Medical Campus, 21400 Kuala Terengganu, Terengganu, Malaysia \\ ${ }^{2}$ Faculty of Bioresources and Food Industry \\ ${ }^{3}$ Agriculture Production and Food Innovation Research Institute \\ Universiti Sultan Zainal Abidin, Tembila Campus, 22200 Besut, Terengganu, Malaysia \\ *Corresponding author: raousm@gmail.com
}

Received: 14 April 2015; Accepted: 3 August 2016

\begin{abstract}
Inflammatory diseases are an important health concern, and the growing rate is on the rise. Finding a safe drug for these diseases remains an important issue. The study aimed to determine the nitric oxide (NO) scavenging as well as anti-inflammatory activities of Musa paradisiaca (banana). Musa paradisiaca plant parts used in this study namely tepal, skin (peel) and flesh (pulp) were extracted with methanol (tepal, flesh and skin), ethanol (tepal) and water (tepal) using cold maceration technique. Phytochemicals screening of the extracts was carried out. The ability of the extracts to scavenge NO radical was evaluated using Griess reagent. The anti-inflammatory activity of the extracts was assessed by evaluating the ability of the extract to inhibit RAW 264.7 macrophage cell line from generating harmful NO induced by bacterial lipopolysaccharide (LPS). In order to determine the toxicity of the extracts to the cells while exerting its anti-inflammatory activity,cytotoxicity was measured using MTT [3-(4,5-dimethylthiazol-2-yl)-2,5-diphenyltetrazolium bromide] assay.The extract was found to contain bioactive chemicals like flavonoids, saponins, phenols, etc. Maximum NO radical inhibition of $41.05 \%$ was recorded in the tepal aqueous extract, and minimum inhibition of $22.34 \%$ was recorded in the flesh extract. All others showed mild inhibition as well. Flesh extract has the highest NO (generated by LP) inhibitory activity, with the maximum inhibition of $52.21 \%$ at $250 \mu \mathrm{g} / \mathrm{mL}$, followed by tepal aqueous extract with maximum inhibition of $48.16 \%$ at $62.5 \mu \mathrm{g} / \mathrm{mL}$. The least inhibition was noted in the tepal methanol extract that has the maximum inhibition of $19.63 \%$ at $\quad 62.5 \mu \mathrm{g} / \mathrm{mL}$. The viability of the activated macrophages was not affected by the extracts as confirmed by the MTT assay, thereby indicating that the inhibition of NO synthesis by the extracts was not due to cytotoxic effects. Overall, Musa paradisiaca plant parts have the potential as anti-inflammatory and studies in this aspect should be intensified.
\end{abstract}

Keywords: anti-Inflammation, MTT, Musa paradisiaca, RAW 264.7

\section{Abstrak}

Penyakit radang merupakan gejala penyakit yang semakin mendapat perhatian dan kadar kedapatan (penyakit) semakin meningkat. Pencarian ubat yang selamat untuk penyakit ini masih menjadi isu penting. Kajian ini bertujuan menentukan aktiviti pemerangkapan nitrik oksida (NO) serta anti radang oleh Musa paradisiaca (pisang). Bahagian - bahagian Musa paradisiaca yang diguna dalam kajian ini adalah jantung, kulit (kupasan) dan isi (pulpa). Sampel - sampel telah diekstrak dengan metanol (jantung, kulit dan isi), etanol (jantung) dan air (jantung) menggunakan kaedah rendaman sejuk. Penyaringan fitokimia keatas ekstrak telah dijalankan. Keupayaan ekstrak memerangkap radikal NO dinilai menggunakan reagent Griess. Aktiviti anti radang 
oleh bahan terekstrak telah ditentukan melalui penilaian terhadap keupayaan menghalang sel makrofaj RAW 264.7 daripada menghasilkan NO yang diaruh oleh lipopolisakarida (LPS) bakteria. Bagi menentukan ketoksikkan ekstrak terhadap sel semasa ianya bertindak sebagai anti radang, tahap sitotiksik telah diukur menggunakan ujian MTT [3-(4,5-dimetiltiazol-2-il)-2,5difeniltetrazolium bromida]. Kajian mendapati bahawa ekstrak pisang mengandungi bahan kimia bioaktif seperti flavonoids, saponins, fenols, dan lain - lain. Perencatan maksima radikal NO sebanyak $22.34 \%$ telah direkodkan bagi ekstrak akueus jantung pisang, dan kadar perencatan minima telah direkodkan pada ekstrak isi pisang. Kesemua ekstrak yang lain menunjukkan perencatan yang rendah. Ekstrak isi pisang mempunyai aktiviti perencatan NO (yang dihasilkan oleh LP) tertinggi dengan perencatan maksima $52.21 \%$ pada kepekatan $250 \mu \mathrm{g} / \mathrm{mL}$, diikuti oleh ekstrak akueus jantung pisang dengan perencatan maksima $48.16 \%$ pada kepekatan $62.5 \mu \mathrm{g} / \mathrm{mL}$. Perencatan terendah telah dicatatkan oleh ekstrak metanol jantung pisang, yang mempunyai perencatan maksima $19.63 \%$ pada kepekatan $62.5 \mu \mathrm{g} / \mathrm{mL}$. Kebolehhidupan makrofaj yang diaktifkan tidak terjejas oleh ekstrak sepertimana yang dibuktikan oleh ujian MTT, ia menunjukkan bahawa sintesis NO oleh ektrak bukanlah dari kesan sitotoksik. Secara keseluruhan, bahagian - bahagian Musa paradisiacal mempunyai potensi sebagai anti radang dan kajian mengenainya perlu diperluaskan.

Kata kunci: anti radang, MTT, Musa paradisiaca, RAW 264.7

\section{Introduction}

The body is continuously expose to various noxious agents. This ranges from pathogens (bacteria, viruses, and fungi) to various physical and chemical agents as well as environmental pollutions that result in cell injury or death $[1,2]$. The body cells resist and eliminate the effect of these agents through an inherent process termed "inflammation".

Recently, the roles of many inflammatory cells and a large number of inflammatory mediators in many pathologies not previously known to be associated to inflammation have been identified. Such pathologies include Alzheimer's disease and cardiovascular disorders including atherosclerosis, as well as cancer [3,4]. For example; acute infection is characterized by elevated myeloperoxidases, ROS and IL-6, which in severe disease serve as an index, in viral and bacterial causes [5], increased nitric oxide (NO) in exhaled air reflected airway inflammation in asthma patients $[6,7,8]$.

Nitric oxide is an important signalling molecule involved in diverse physiological and pathophysiological mechanisms in cardiovascular, nervous and immunological systems. It has contrasting roles in living organisms. It acts as a biological mediator, control blood vessel tone in vascular systems and is an important agent in host defence effector in the immune system. However, it is a free oxygen radical and has cytotoxic effect in pathological processes, particularly in inflammatorydisorders [9-12].Inhibition of iNOS (inducible nitric oxide synthase) may be beneficial for the treatment of inflammatory disease $[13,14]$. Evidence showed that drugs obtained from natural sources can modulate various inflammatory mediators (arachidonic acid metabolites, peptides, cytokines, excitatory amino acids, etc.), the production and/or action of second messengers (cGMP, cAMP, protein kinases, and calcium), the expression of transcription factors such as AP-1, NF- $\mathrm{KB}$, and proto-oncogenes (c-jun, $c-f o s$, and $c-m y c)$, and the expression of key pro-inflammatory molecules such as inducible NO synthase (iNOS), cyclooxygenase (COX-2), cytokines (IL-1 $\beta, \mathrm{TNF}-\alpha$ ), neuropeptides and proteases [15].

Plants have been the basis of many traditional medicine systems throughout the world for thousands of years and remain the primary new source of structurally significant chemical substances that lead to the development of innovative drugs [16,17]. Banana is one of the oldest and well-known fruit worldwide. It has no seeds; it is delicious and available throughout the seasons at an affordable cost. Many traditional uses of banana have been documented. In addition to its nutritional value, a number of biological activities studies have been carried out on banana and these studies prove it to possess bioactivities including anti-hyperglycaemic, anti-ulcerogenic, antioxidant, antihypertensive, cardiac depressant, diuretic, anti-tumoral, bronchodilatory, expectorant, oral contraceptive, antibacterial, antifungal, among others [18].

Hence, the aim of this study is to search for a new safer agent from the medicinal plant that has both NO radical scavenging as well as anti-inflammatory activities is significant to the field of medicine and health sciences. 


\section{Plant material: Collection and preparation}

\section{Materials and Methods}

Musa paradisiaca, fruit and tepal, were obtained from Kuala Terengganu, Malaysia. Samples were identified and authenticated by Dr. Khamsah Suryati Mohd from the Faculty of Bioresources and Food industry, Universiti Sultan Zainal Abidin. The skin (peel) was skinned away and both the skin and the flesh (pulp) were cut and weighed by an electrical balance $\left(1.45 \mathrm{~kg}\right.$ and $3.28 \mathrm{~kg}$ ) respectively, before dried in a drier at $45^{\circ} \mathrm{C}$, their dry weights were $0.41 \mathrm{~kg}$ and $0.21 \mathrm{~kg}$ respectively. After drying, samples were blended into powder, using an electrical blender, and the weights were $0.21 \mathrm{~kg}$ and $0.10 \mathrm{~kg}$. The tepal was also processed in a similar way and weighed $(3 \mathrm{~kg})$ and dried at 40 ${ }^{\circ} \mathrm{C}$ and then blended to powder $(0.42 \mathrm{~kg})$.

\section{Extraction procedure}

The freshly prepared flesh, skin and tepal were extracted twice with methanol $(10: 2 \mathrm{~mL} / \mathrm{kg})$ by cold extraction technique and again with ethanol (for the tepal). The samples were kept in the solvents forthree days at room temperature with regular shaking. Aqueous extraction of the tepal was done by boiling the sample in distilled water at $100{ }^{\circ} \mathrm{C}$ on a hot plate. All the extracts were vacuum filtered using Whatman filter paper and made semi-solid by evaporating the solvents using a rotary evaporator.The water extract was concentrated in an oven at $100{ }^{\circ} \mathrm{C}$ to obtain the crude extracts. The crude extracts were kept in fresh vials and refrigerated $\left(4^{\circ} \mathrm{C}\right)$ for further use.

\section{Phytochemical screening}

The phytochemicals screening of the various solvents extract were carried out using standard procedures as described by Trease and Evans[19]. The following tests were carried out qualitatively.

\section{Test for glycosides}

Small amount of the extracts was put in $1 \mathrm{~mL}$ of water in a test tube followed by the addition of $1 \mathrm{~mL}$ of $\mathrm{NaOH}$. A yellow precipitate indicates the presence of glycosides.

\section{Test for phenols}

The extract $(5 \mathrm{mg}$ ) was dissolved in distilled water, and $3 \mathrm{~mL}$ of $10 \%$ lead acetate solution was added. Bulky white precipitates indicated the presence of phenols.

\section{Test for Flavonoids}

A few drops of concentrated hydrochloric acid were added to a small amount of the extract. Immediate development of red color indicates the presence of flavonoids.

\section{Test for Saponins}

$1 \mathrm{~mL}$ of each extract was diluted with distilled water to $20 \mathrm{~mL}$ and shaken in a graduated cylinder for $15 \mathrm{~min}$. The formation of foam of about $1 \mathrm{~cm}$ indicates the presence of saponins.

\section{Pharmacological activities: Nitric oxide (NO) scavenging activity}

For the experiment, sodium nitroprusside $(10 \mathrm{mM})$ in phosphate buffered solution $(\mathrm{pH}=7.4)$ was mixed with various concentrations of the extract prepared in $10 \%$ DMSO and incubated under light at room temperature for 15 min. The same reaction mixture without the tested extract, but the equal amount of the solvent serves as the control (the last well). After the incubation, $0.05 \mathrm{~mL}$ of Griess reagent (1\% sulfanilamide, $2 \% \mathrm{H}_{3} \mathrm{PO}_{4}$ and $0.1 \% \mathrm{~N}-(1-$ naphthyl) ethylenediamine dihydrochloride was added. Ascorbic acid was used as positive control. The absorbance was measured at $546 \mathrm{~nm}$ and the percentage of $\mathrm{NO}$ radical inhibition by the extract was calculated from the formula equation 1 below

$$
[(\mathrm{A} 0-\mathrm{A} 1) / \mathrm{A} 0] \times 100
$$

where $\mathrm{A} 0$ is the absorbance of the control, and $\mathrm{A} 1$ is the absorbance of the extract/standard [20]. $\mathrm{IC}_{50}$ value was obtained by drawing the equation of line from the graph of concentration $(\mu \mathrm{g} / \mathrm{mL})$ versus percentage of inhibition. 
Anti-inflammatory activity: Materials and reagents

RPMI 1640 media (Gibco), dimethyl sulfoxide (DMSO), lipopolysaccharide (LPS, Escherichia coli) and 3-(4,5dimethylthiazol-2-yl)-2,5-diphenyltetrazolium bromide (MTT) were purchased from Sigma Chemical Company, fetal bovine serum (FBS)(Gibco) and penicillin/streptomycin (Penstrep)(Gibco).

\section{Cell culture (seeding and treatment)}

The macrophage cell line, RAW 264.7 was obtained from the cell culture lab, Faculty of medicine, Universiti Sultan Zainal Abidin. The cells were cultured in Roswell Park Memorial Institute (RPMI, 1640) medium supplemented with $1 \%$ pen/strep and $10 \%$ heat-inactivated fetal bovine serum. The cell was incubated, in a humidified incubator, in an atmosphere of $5 \% \mathrm{CO}_{2}$ at $37{ }^{\circ} \mathrm{C}$ and were subcultured twice before the experiment.

RAW 264.7 cells were seeded onto a 96-well plate $\left(1 \times 10^{5}\right.$ cells/well $)$ and incubated for 24 hours for the experiments. The cells were then treated with the samples at concentrations of 250, 125, 62.5, 31.25, and 15.625 $\mu \mathrm{g} / \mathrm{mL}$ and incubated for 1 hour. They were then stimulated with $1 \mu \mathrm{g} / \mathrm{mL}$ of LPS for another 24 hours. The supernatant was gently transferred to new 96-well plates and used for NO determination, while the cells remained in the old plate were used for the MTT assay of cell viability. Samples (stock) were dissolved in DMSO, and the working samples were prepared in the media. The effects of the tested extracts were compared with those of L-N $\mathrm{N}^{6}$ (1-iminoethyl) lysine hydrochloride), a known inhibitor of NO production.

\section{MTT [3-(4,5-dimethylthiazol-2-yl)-2,5-diphenyltetrazolium bromide] assay for cell viability}

MTT is a pale yellow substrate that is reduced by living cells to yield a dark blue formazan product. This process requires an active mitochondrion, and only freshly dead cells do not reduce significant amounts of MTT. After 24 hours incubation with LPS, MTT was added to the medium for 4 hours. At last, the supernatant was removed, and the formazan crystals were dissolved in DMSO and incubated for more 15 minutes at room temperature. Absorbance was measured at $570 \mathrm{~nm}$ with reference $630 \mathrm{~nm}$. The percentage of dead cells was determined using the formula equation 2 .

$$
\text { Cell viability }(\%)=\frac{\text { Test }}{\text { Control }} \times 100
$$

\section{Nitric oxide assay}

Nitric oxide production was assayed by measuring nitrite in the supernatants of cultured RAW 264.7 cells. The assay was carried out as described previously with slight modification [21]. After pre-incubation of RAW 264.7 cells $\left(1 \times 10^{5}\right.$ cells $\left./ \mathrm{mL}\right)$ with LPS $(1 \mu \mathrm{g} / \mathrm{mL})$ for 24 hours, the amount of nitrite, a stable metabolite of NO use as an indicator of $\mathrm{NO}$ production, in the culture medium was measured using the Griess reagent (1\% sulfanilamide and $0.1 \%$ naphthylethylenediamine dihydrochloride in $2.5 \%$ phosphoric acid). A volume of $50 \mu \mathrm{L}$ of the cell culture medium was mixed with $50 \mu \mathrm{L}$ of the Griess reagent. Subsequently, the mixture was incubated at room temperature for $15 \mathrm{~min}$,and the absorbance was measured at $540 \mathrm{~nm}$ in a microplatereader. Fresh culture medium was used as a blank in every experiment. The quantity of nitrite was determined from a sodium nitrite standard curve as expressed in equation 3.

$$
\text { Inhibition }(\%)=\frac{\text { Control-Test }}{\text { Control }} \times 100
$$

\section{Phytochemicals detected in Musa paradisiaca}

\section{Results and Discussion}

The various solvent extracts of Musa paradisiaca, prepared in this work showed the presence of some of the tested phytochemicals like flavonoids, phenols, glycosides among others. Research into natural products often, is aided by ethnopharmacological knowledge and has brought enormous contributions to drug production by providing novel chemical structures and mode of action [22,23]. Methanol and ethanol tepal extracts showed the presence of glycosides and phenols in abundance. Flavonoids and saponins were also detected in these extracts. Tepal aqueous showed the presence of glycosides, phenols, with abundant flavonoids yet saponins are not detected in this extract. 
In both skin and flesh methanol extracts, glycosides and phenols were detected with abundant flavonoids in the latter and normal in the former (Table 1).

Table 1. Phytochemicals from the various solvent extracts of Musa paradisiaca

\begin{tabular}{lcccc}
\hline Extract & Glycosides & Phenols & Flavonoids & Saponins \\
\hline Tepal methanol & ++ & ++ & + & + \\
Tepal Ethanol & ++ & ++ & + & + \\
Tepal Aqueous & + & + & ++ & - \\
Skin & + & + & ++ & - \\
Flesh & + & + & + & - \\
\hline
\end{tabular}

Note: $++=$ present in abundance. $+=$ present. $-=$ Absent

Plant secondary metabolites, are essential sources of many food ingredients and plant chemicals (phytochemicals) [24]. Plants are known to produce many secondary metabolite compounds like alkaloids, cyanogenic glycosides, glucosinolates, flavonoids, saponins, steroids and terpenoids to screen themselves from the attack of naturally occurring pathogens, insect pests and environmental stresses. Recent researches showed that many phytochemicals can protect humans against various diseases [25]. Many phytochemicals are present in herbs, and each has its distinct work. The health benefits attributed to these phytochemicals include; antioxidant, antimicrobial, antiinflammatory, cancer preventive, antidiabetic and antihypertensive effects [26,27].

Previous studies confirm to the current finding. Research by Jini et al. [28], showed that the flower methanol, ethanol and aqueous extracts of Musa paradisiaca containing flavonoids and phenolic compounds. Phytochemical screening of Musa paradisiaca flower revealed the presence of glycosides, flavonoids and tannins in ethanolic extract and flavonoids, saponins, glycosides and tannins in ethanol-water extract (1:1) [29]. Preliminary phytochemical screening of dried leaves and fruit peels of Musa paradisiaca revealed the presence of some glycosides, anthocyanins, tannins, flavonoids as well as carbohydrates [30,31,32]. These phytochemicals have been reported to play multiple biological and pharmacological roles (antibacterial, antihypertensive, antidiabetic and antiinflammatory activities) [33].

The obvious roles played by these phytochemicals in both therapeutic and nutritional fields, contribute to the role played by this plant, Musa paradisiaca particularly tepal and fruit (skin and flesh) in the field of medicine and health sciences.

Effect of Musa paradisiaca on nitric oxide generated by sodium nitroprusside

The extracts showed mild inhibition against the NO produced by the sodium nitroprusside. Maximum inhibition of $41.05 \%$ was recorded in the tepal aqueous extract, and minimum inhibition of $22.34 \%$ has been registered in the flesh extract; all others showed mild inhibition as well (Table 2).

Table 2. Percentage of NO inhibition by tepal, skin and flesh extracts with the inhibitory concentration

\begin{tabular}{lcc}
\hline Sample & $\begin{array}{c}\text { Maximum inhibition } \\
\mathbf{( \% )}\end{array}$ & $\begin{array}{c}\text { Concentration } \\
(\boldsymbol{\mu g} / \mathbf{m L})\end{array}$ \\
\hline Tepal methanol & 32.36 & 1000 \\
Tepal ethanol & 40.58 & 250 \\
Tepal aqueous & 41.05 & 1000 \\
Skin & 35.94 & 1000 \\
Flesh & 22.34 & 500 \\
Ascorbic acid & 84.43 & 1000 \\
\hline
\end{tabular}


Nitric oxide is an important chemical mediator produced by endothelial cells, macrophages, neurons, to mention a few and is involved in the regulation of many different physiological processes [34]. An excess amount of NO is associated with several diseases [35], such as its implication in inflammation, cancer and other pathological conditions. It is produced in biological tissues by specific nitric oxide synthases (NOSs), which metabolize arginine to citrulline in which process it is formed via a five electron oxidative reaction [36]. Incubation of solutions of sodium nitroprusside in PBS at $25{ }^{\circ} \mathrm{C}$ resulted in the linear time dependent nitrite production, which is reduced by the tested extracts. Powdered drug of plant parts of Drymariadiandra Blume were separately extracted with methanol-water in ratio 4:1. The extracts from this plant of both hill and plain areas executed very less scavenging power against NO [37].

\section{Effect of Musa paradisiaca - tepal, skin and flesh on LPS induced NO (anti-inflammatory activity) and RAW 264.7 cell viability}

The Griess reaction, a spectrophotometric determination of nitrite level, was carried out to measure the nitrite levels in the conditioned medium of RAW 264.7 cells treated with LPS. Sodium nitrite $\left(\mathrm{NaNO}_{2}\right)$ was used as a standard compound for the standard curve (Figure 1). The NO concentrations were obtained using the standard curve equation: $\mathrm{y}=0.005 \mathrm{x}+0.0589$, where $\mathrm{y}$ is absorbance at $540 \mathrm{~nm}$ and $\mathrm{x}$ is the NO concentration in $\mu \mathrm{M}$. The inhibitory activity of the extracts towards NO generated by LPS-activated macrophage was obtained from the calculated value of $x$.

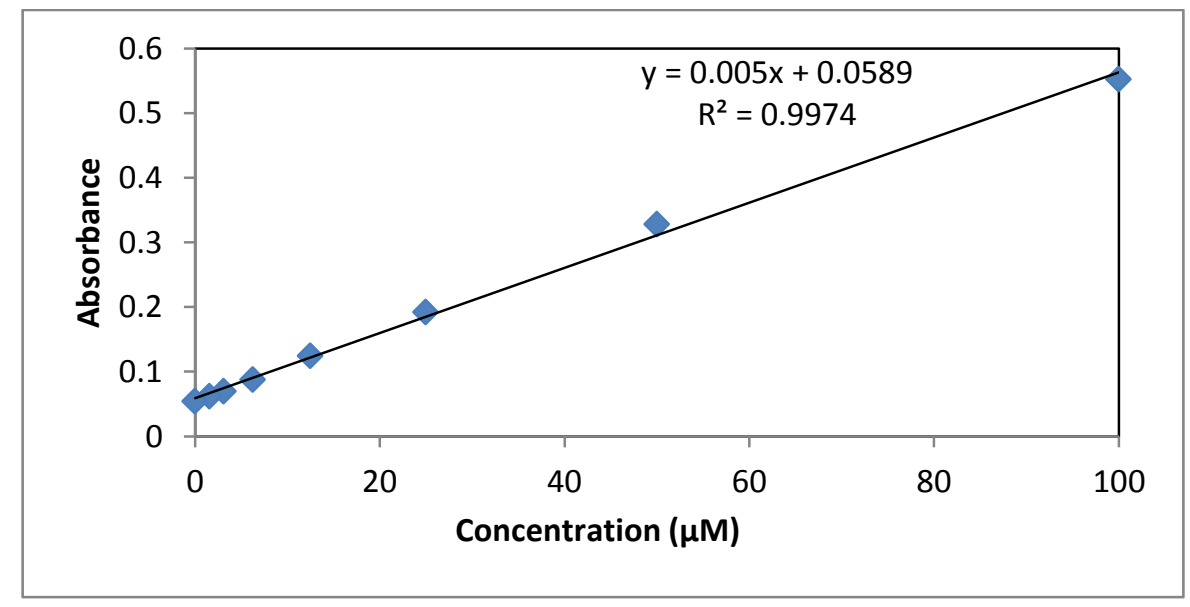

Figure 1. $\mathrm{NaNO}_{2}$ standard curve, use to obtain $\mathrm{NO}$ concentration.

The results from this findings showed that flesh extract has the highest NO inhibitory activity, with the maximum inhibition of $52.21 \%$ at $250 \mu \mathrm{g} / \mathrm{mL}$, followed by tepal aqueous extract with maximum inhibition of $48.16 \%$ at 62.5 $\mu \mathrm{g} / \mathrm{mL}$. The least inhibition was noted in the tepal methanol extract that has the highest inhibition of $19.63 \%$ at 62.5 $\mu \mathrm{g} / \mathrm{mL}$ (Table 3). The inhibition of NO, generated by the LPS induced macrophage, by the extracts is similar to that of NO generated by sodium nitroprusside, as discussed in the NO radical scavenging assay. This proves that Musa paradisiaca has NO inhibitory activity, which signifies its anti-inflammatory activity.

Table 4 and Figure 2 showed that the number of viable activated macrophages was not altered by the extracts as determined by MTT assay. This indicates that, the inhibition of NO synthesis by the extracts was not due to cytotoxic effects.

The higher NO inhibition by the fruit correspond to the epidemiological data that suggest that lower incidences of certain chronic diseases such as atherosclerosis, arthritis, diabetes, acquired immune deficiency syndrome (AIDS) 
are associated with frequent intake of fruits and vegetables [38,39,40]. Flavonoids constituent may also contribute to this activity as many studies prove that consumption of flavonoid-rich foods exhibited regression of inflammatory diseases [41].

Table 3. Maximum NO (generated by LPS) inhibitory concentration of Musa paradisiaca tepal, skin and flesh extracts and their concentrations.

\begin{tabular}{lcc}
\hline Sample & $\begin{array}{c}\text { Maximum NO inhibition } \\
(\mathbf{\%})\end{array}$ & $\begin{array}{c}\text { Concentration } \\
(\boldsymbol{\mu g} / \mathbf{m L})\end{array}$ \\
\hline Tepal methanol & 19.63 & 62.5 \\
Tepal ethanol & 46.08 & 125 \\
Tepal aqueous & 48.16 & 62.5 \\
Skin & 30.6 & 250 \\
Flesh & 52.21 & 250 \\
Standard & 52 & 250 \\
\hline
\end{tabular}

Table 4. Maximum and minimum percent cell viability of Musa paradisiaca tepal, skin and flesh and their various concentrations

\begin{tabular}{lcccc}
\hline \multicolumn{5}{c}{ Cell viability (\%) } \\
\hline Sample & Maximum & $\begin{array}{c}\text { Concentration } \\
(\boldsymbol{\mu g} / \mathbf{m L})\end{array}$ & Minimum & $\begin{array}{c}\text { Concentration } \\
(\boldsymbol{\mu g} / \mathbf{m L})\end{array}$ \\
\hline Tepal methanol & 102.4 & 62.5 & 15 & 250 \\
Tepal ethanol & 119.84 & 62.5 & 75 & 250 \\
Tepal aqueous & 83.43 & 15.625 & 36 & 250 \\
Skin & 87.14 & 15.625 & 43 & 250 \\
Flesh & 100.36 & 62.5 & 68 & 250 \\
Standard & 90.97 & 62.5 & 80.96 & 250 \\
\hline
\end{tabular}

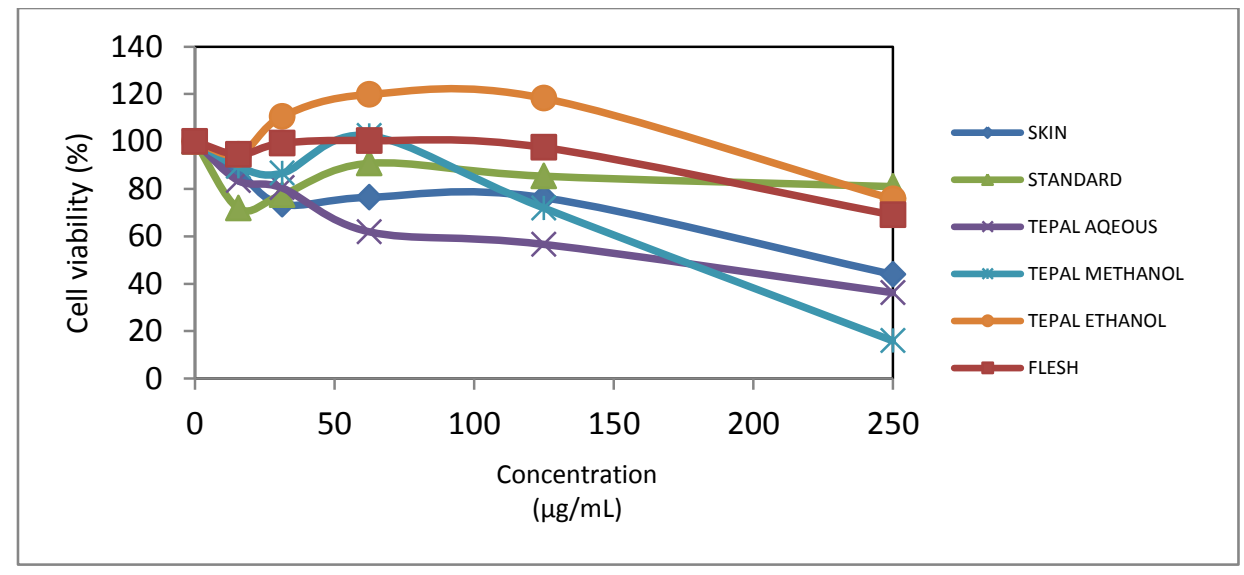

Figure 2. Percent cell viability of the tepal, skin and flesh extracts as determined by MTT 
Inflammation is the normal physiological and immune response to tissue injury. More blood supply, enhanced vascular permeability and migration of immune cells occur at the damaged sites. The inflammatory process is a protective reaction that takes place in response to trauma, infection, tissue injury or noxious stimuli $[42,43,44]$. In this process, activated inflammatory cells (neutrophils, eosinophil, mononuclear phagocytes and macrophages) released abnormal levels of NO, prostaglandin E2 (PGE2) and cytokines, such as interleukin (IL)-1ß, IL-6, and tumour necrosis factor (TNF).These substances not only cause cell and tissue damage but also activate macrophages in diseases like rheumatoid arthritis and chronic hepatitis [45 - 48].

NO is the main product, which formationis regulated by the NOSs. The NOSs include iNOS (inducible nitric oxide synthases), eNOS (endothelial nitric oxide synthases) and nNOS (neuronal nitric oxide synthases). Most significantly, iNOS is highly expressed in macrophages and its activation leads to organ destruction in some inflammatory and autoimmune diseases [49,50]. During inflammation, macrophages play a fundamentalrole in controlling many different immunopathological phenomena, including the overproduction of pro-inflammatory cytokines and inflammatory mediators such as IL-1B, IL- 6, NO, iNOS, COX-2 and TNF. Indeed, many of inflammatory stimuli, such as LPS and proinflammatory cytokines, activate immune cells to up-regulate such inflammatory states, and these are therefore useful targets in the development of new anti-inflammatory drugs and investigation of the anti-inflammatory molecular mechanisms of a potential drug [51,52]. LPS stimulation alone has been demonstrated to induce iNOS transcription and its protein synthesis, in murine macrophage RAW 264.7 cells, with a corresponding rise in NO production. Moreover, LPS stimulation has also been shown to induce IKB proteolysis and NF- $\mathrm{kB}$ nuclear translocation [53,54]. Hence, this cell system is a splendid model for drug screening and the subsequent evaluation of potential inhibitors against iNOS and NO production.

Varieties of phytoconstituents are responsible for anti-inflammatory activity in plants, including phenolics, alkaloids, and terpenoids [55] and phenols are among the phytochemical presents in the extracts. Plants are blessed with many different phytochemical such as, vitamins, phenolics, terpenoids, lignins, tannins, flavonoids, quinones, coumarins, alkaloids, amines, betalains, and other metabolites, which are rich in antioxidant activity [56,57]. Several researches have shown that many of these antioxidant compounds possess anti-inflammatory, antiatherosclerotic, anti-tumor, anti-mutagenic, anti-carcinogenic, anti-bacterial, and anti-viral activities [58,59]. Saponins present in the tepal ethanol extract may as well, contribute to its anti-inflammatory activity, as soybean saponins were reported to downregulate the expression of PGE2 and NO metabolism at mRNA and protein levels, showing these saponins as chemicals that possess chemopreventive activity through the downregulation of COX-2 or iNOS [60]. Another report also showed that saponins from quinoa possess potent anti-inflammatory activities [61].

Many compounds from medicinal plants origin have been demonstrated as inhibitors of the expression of iNOS in LPS-activated macrophages. Their structures can be categorized as sesquiterpene $[62,63]$, polyacetylenes [64] and lignans [65]. Thus, plants demonstrating inhibitory activity against NO production will be promising candidates for the isolation of active components exhibiting iNOS inhibitory activity, which may have therapeutic potential for the treatment of inflammation accompanying overproduction of NO.

These results indicate that flesh, tepal ethanol and aqueous extracts may suppress NO generation by inhibiting the NOS enzyme activity similar to the NOS inhibitor L-N ${ }^{6}$-(1-imino ethyl) lysine hydrochloride (the standard). It is recommended that the extracts, which inhibits NO production through inhibiting iNOS enzyme activity, has beneficial therapeutic effects in the management of inflammatory diseases. These results showed that the tepal ethanol, aqueous and flesh extracts, did not alter the cell viability even at $250 \mu \mathrm{g} / \mathrm{mL}$. Therefore, inhibition of LPSinduced NO production by these extracts was not due to its cytotoxicity on the cells.

\section{Conclusion}

Musa paradisiaca (banana) is a plant that has been used since ancient times both as nutrient and in the treatment of many diseases. The plant is a good candidate for evaluating the nitric oxide scavenging as well as anti-inflammatory potentials due to its proven positive pharmacological activities by many researchers. Both tepal and fruit extracts 
demonstrated good nitric oxide scavenging as well as anti-inflammatory activities. Hence, these plant parts need more scientific attention in order to actualize its potentialities in the fields of medicine and health sciences.

\section{Acknowledgement}

The researchers acknowledged the effort of chemistry and cell culture labs staff, in the Faculty of Medicine, of Universiti Sultan Zainal Abidin (UniSZA) for their help in this research. The effort of Ainul Syamira, a research assistant at UniSZA, is also appreciated.

\section{References}

1. O’Byrne, K. J. and Dalgleish, A. G. (2001). Chronic immune activation and inflammation as the cause of malignancy. British Journal of Cancer, 85:473 - 483.

2. O’Byrne, K. J., Dalgleish, A. G., Browning, M. J., Steward, W. P. and Harris, A. L. (2000), The relationship between angiogenesis and the immune response in carcinogenesis and the progression of malignant disease. European Journal of Cancer, 36: 151 - 169.

3. Akiyama, H., Barger, S., Barnum, S., Bradt, B., Bauer, J., Cole, G. M., Cooper, N. R., Eikelenboom, P., Emmerling, M. and Fiebich, B. L. (2000). Inflammation and Alzheimer's disease. Neurobiology of Aging, 21: $383-421$.

4. Libby, P., Ridker, P. M. and Maseri, A. (2002). Inflammation and atherosclerosis. Circulation, 105: 1135 1143.

5. Kulander, L., Pauksens, K. and Venge, P. (2001). Soluble adhesion molecules, cytokines and cellular markers in serum in patients with acute infections. Scandinavian Journal of Infectious Diseases, 33: 290 - 300.

6. Bellanti, J. A. (1998). Cytokines and allergic diseases: clinical aspects. Allergy Asthma Proceeding, 19: 337 341.

7. Romagnani, S. (2000). T-cell subsets (Th1 versus Th2). Ann. Allergy Asthma. Immunology, 85: 9- 21.

8. Silvestri, M., Sabatini, F., Defilippi, A. C., Ghiro, L., Baraldi, E. and Rossi, G. A. (2003). A marker of asthma inflammation: orally exhaled nitric oxide. Allergy and Clinical Immunology International, 15: 37 - 43.

9. Alderton, W. K., Cooper, C. E. and Knowles, R. G. (2001). Nitric oxide synthases: structure, function and inhibition. Biochemical Journal, 357(P3): 593 - 615.

10. Bogdan, C. (2001). Nitric oxide and the immune response. Nature Immunology, 2(10): 907 -916.

11. Dawn, B. and Bolli, R. (2002). Role of nitric oxide in myocardial preconditioning. Annals of the New York Academy of Sciences, 962: $18-41$.

12. Moncada, S. and Higgs, E. A. (1991). Endogenous nitric oxide: physiology, pathology and clinical relevance. European Journal of Clinical Investigation, 21(4): 361 - 374.

13. Aktan, F., Henness, S., Roufogalis, B. D. and Ammit, A. J. (2003). Gypenosides derived from Gynostemma pentaphyllum suppress NO synthesis in murine macrophages by inhibiting iNOS enzymatic activity and attenuating NF-B-mediated iNOS protein expression. Nitric Oxide: Biology and Chemistry, 8(4): 235 - 242.

14. Kroncke, K. D., Fehsel, K. and Kolb-Bachofen, V. (1998). Inducible nitric oxide synthase in human diseases. Clinical Experimental Immunology, 113(2): 147 - 156.

15. Kim, Y. S., Young, M. R., Bobe, G., Colburn, N. H. and Milner, J. A., (2009). Bioactive food components, inflammatory targets, and cancer prevention. Cancer Prevention Research, 2: 200 - 208.

16. Fabricant, D. S. and Farnsworth, N. R. (2001). The value of plants used in traditional medicine for drug discovery. Environmental Health Perspective, 109: 69 - 75.

17. Jachak, S. M. and Saklani, A., (2007). Challenges and opportunities in drug discovery from plants. Current Science, 92: $1251-1257$.

18. Sharma, P. C., Yelne, M. B., Dennis and Kadali J. J. (2002). In: Data base on medical plants used in Ayurveda and Siddha. New Delhi: Public Printing, 5: 78 - 93.

19. Trease, G. E. and Evans, W. C. (1989). Trease and Evan's Textbook of Pharmacognosy. $13^{\text {th }}$ Ed. London: Cambridge University Press: pp. 546

20. Sreejayan, N. and Rao, M. N. A. (1997). Nitric oxide scavenging by curcuminoids. Journal of Pharmacy and Pharmacology, 49(1): $105-107$.

21. Yoon, W. J., Kim, S. S., Oh, T. H., Lee, N. H. and Hyun, C. G. (2009). Abies koreana essential oil inhibits drug-resistant skin pathogen growth and LPS-induced inflammatory effects of murine macrophage. Lipids, 44: $471-476$. 
22. Sheeba, M. S. and Asha, V. V. (2006). Effect of Cardiospermum halicacabum on ethanol-induced gastric ulcers in rats. Journal of Ethnopharmacology, 106(1): 105 - 110.

23. Bohlin, L., Goransson, U., Alsmark, C., Weden, C. and Backlund, A. (2010). Natural products in modern life science. Phytochemistry Reviews, 9(2): 279 - 301.

24. Doss, A. and Anand, S. P. (2012). Preliminary phytochemical screening of Asteracanthalongifolia and Pergularia daemia. World Applied Science Journal, 18(2): 233 - 235.

25. Kubmarawa, D., Khan, M. E., Punah, A. M. and Hassan, M. (2008). Phytochemical screening and antibacterial activity of extracts from Parkia clappertoniana keay against human pathogenic bacteria. Journal of Medical Plants Research; 2(12): $352-355$.

26. Savithramma, N., Linga Rao, M. and Suhrulatha, D. (2011). Screening of medicinal plants for secondary metabolites. Middle-East Journal of Science Research; 8: 579 - 584.

27. Rupasinghe, H. P., Jackson, C. J., Poysa, V., Berado, C. D., Bewley, J. D. and Jenkinson, J. (2003). Soyasapogenol A and B distribution in Soybean (Glycine max (L.) Merr.) in relation to seed physiology, genetic variability and growing location. Journal of Agricultural and Food Chemistry, 51: 5888 - 5894.

28. Jini, J., David, P., Kavitha, M. P., Dineshkumar, B., Jalaja S. Menon, Bhat, A. R. and Krishnakumar, K. (2014). Preliminary phytochemical screening and in vitro antioxidant activity of Banana flower (Musa paradisiaca AAB Nendran variety). Journal of Pharmacy Research, 8(2): 144 - 147.

29. Sunil Jawla, Kumar, Y. and Khan, M. S. Y. (2012). Antimicrobial and antihyperglycemic activities of Musa paradisiaca flowers. Asian Pacific Journal of Tropical Biomedicine, 2(2): 914 - 918.

30. Anhwange, B. A. (2008). Chemical composition of Musa sapientum (Banana) peels. Journal of Food Technology, 6(6): $263-268$.

31. Archibald, J. G. (1949). Nutrient composition of banana skins. Journal of Dairy Science; 32: 969 -971.

32. Alisi, C. S., Nwanyanwu, C. E., Akujobi, C. O. and Ibegbulem, C. O. (2008). Inhibition of dehydrogenase activity in pathogenic bacteria isolates by aqueous extracts of Musa paradisiaca (var Sapientum). African Journal of Biotechnology, 7(12): 1821 - 1825.

33. Middleton, E. J. and Kandaswanmi, C. (1992). Effects of flavonoids on immune and inflammatory cell function. Biochemical Pharmacology, 43(6): $1167-1179$.

34. Lata, H. and Ahuja, G. K. (2003). Role of free radicals in health and disease. Indian Journal of Physiology Allied Science, 57: 124 - 128.

35. Lalenti, S., Moncada, M. and Di Rosa (1993). Modulation of adjuvant arthritis by endogenous nitric oxide. British Journal of Pharmacology, 110: 701 - 705.

36. Ross, R. (1993). The pathogenesis of atherosclerosis: A perspective for the 1990's. Nature, 362: 801- 809.

37. Palash, M., Tarun, K. M. and Mitali, G. (2009). Free-radical scavenging activity and phytochemical analysis in the leaf and stem of Drymaria diandra Blume. International Journal Integrative Biology, 7(2): $81-83$.

38. Ames, B. N., Shigenaga, M. K. and Hagen, T. M. (1993). Oxidants, antioxidants and the degenerative diseases of aging. Proceeding National Academy Science, 90: 7915 - 7922.

39. Chu, Y. F., Sun J., Wu X. and Liu, R. H. (2002). Antioxidant and antiproliferative activities of common vegetables. Journal Agricultural and Food Chemistry, 50: 6910 - 6916.

40. Choi, C. W., Kim, S. C., Hwang, S. S., Choi, B. K., Ahn, H. J., Lee, M. Y., Park, S. H. and Kim, S. K. (2002). Antioxidant activity and free radical scavenging capacity between Korean medicinal plants and flavonoids by assay-guided comparison. Plant Science, 163: 1161 - 1168.

41. Mennen, L. I., Sapinho, D., de Bree, A., Arnault, N., Ber Trais, S., Galan, P. and Hercberg, S. (2004). Consumption of foods rich in flavonoids is related to a decreased cardiovascular risk in apparently healthy French women. Journal of Nutrition, 134(4): 923 - 926.

42. Zedler, S. and Faist, E. (2006). The impact of endogenous triggers on trauma-associated inflammation. Current Opinion in Critical Care, 12: 595 - 601.

43. Mariathasan, S. and Monack, D. M., (2007). Inflammasome adaptors and sensors: intracellular regulators of infection and inflammation. Nature Review of Immunology, 7: $31-40$.

44. Choy, C. S., Hu, C. M., Chiu, W. T., Lam, C. S., Ting, Y., Tsai, S. H. and Wang, T. C. (2008). Suppression of lipopolysaccharide-induced of inducible nitric oxide synthase and cyclooxygenase- 2 by Sanguisdraconis, a dragon's blood resin, in RAW 264.7 cells. Journal of Ethnopharmacology, 115: 455 - 462. 
45. Vane, J. R., Mitchell, J. A., Appleton, I., Tomlinson, A., Bishop-Bailey, D., Croxtall, J. and Willoughby, D. A. (1994). Inducible isoforms of cyclooxygenase and nitric-oxide synthase in inflammation. Proceedings of the National Academy of Sciences, 91: 2046 - 2050.

46. Kasama, T., Miwa, Y., Isozaki, T., Odai, T., Adachi, M. and Kunkel, S. L. (2005). Neutrophil-derived cytokines: potential therapeutic targets in inflammation. Current Drug Targets - Inflammation and Allergy, 4: $273-279$.

47. Wolf, A. M., Wolf, D., Rumpold, H., Ludwiczek, S., Enrich, B., Gastl, G., Weiss, G. and Tilg, H., (2005). The kinase inhibitor imatinib mesylate inhibits TNF-\{alpha\} production in vitro and prevents TNF-dependent acute hepatic inflammation. Proceedings of the National Academy of Sciences, 102: 13622 - 13627.

48. Cheon, H., Rho, Y. H., Choi, S. J., Lee, Y. H., Song, G. G., Sohn, J., Won, N. H. and Ji, J. D. (2006). Prostaglandin E2 augments IL-10 signaling and function. Journal of Immunology, 177: $1092-2100$.

49. Esposito, E. and Cuzzocrea, S., (2007). The role of nitric oxide synthases in lung inflammation. Current Opinion in Investigational Drugs, 8: $899-909$.

50. Murakami, A. and Ohigashi, H. (2007). Targeting NOX, INOS and COX-2 in inflammatory cells: Chemoprevention using food phytochemicals. International Journal of Cancer; 121: $2357-2363$.

51. Zeilhofer, H. U. and Brune, K., (2006). Analgesic strategies beyond the inhibition of cyclooxygenases. Trends Pharmacology Science, 27: 467 - 474.

52. Jachak, S. M. (2007). PGE synthase inhibitors as an alternative to COX-2 inhibitors. Current Opinion in Investigational Drugs, 8: $411-415$.

53. Xie, Q. W., Kashiwabara, Y. and Nathan, C. (1994). Role of transcription factor NFkappa B/Rel in induction of nitric oxide synthase. Journal of Biology Chemistry, 269: 4705 - 4708.

54. Henkel, T., Machleidt, T., Alkalay, I., Konke, M., Ben-Neriah, Y. and Baeuerle, P. A. (1993). Rapid proteolysis of I kappa B-alpha is necessary for activation of transcription factor NF-kappa B. Nature, 365: 182 $-185$.

55. Arya, V. and Arya, M. L. (2011). A review on anti-inflammatory plant barks. International Journal of Pharmtech Research, 3: $899-908$.

56. Zheng, W. and Wang, S. Y. (2001). Antioxidant activity and phenolic compounds in selected herbs. Journal of Agricultural and Food Chemistry, 49(11): 5165 - 5170.

57. Cai, Y. Z., Sun, M. and Corke, H. (2003). Antioxidant activity of betalains from plants of the Amaranthaceae. Journal of Agricultural Food Chemistry, 51(8): 2288 - 2294.

58. Sala, A., Recio, M. D., Giner, R. M., Manez, S., Tournier, H., Schinella, G. and Rios, J. L. (2002). Antiinflammatory and antioxidant properties of Helichrysum italicum. Journal Pharmacy and Pharmacology, 54(3): $365-371$.

59. Rice-Evans, C. A., Miller, N. J., Bolwell, P. G., Bramley, P. M. and Pridham, J. B. (1995). The relative activities of Plant-derived polyphenolic flavonoid. Free Radical Research, 22: 375 - 383.

60. Kang, J. H., Sung, M. K., Kawada, T., Yoo, H., Kim, Y. K., Kim, J. S. and Yu, R. (2005). Soybean saponins suppress the release of proinflammatory mediators by LPS-stimulated peritoneal macrophages. Cancer Letters, 230: $219-227$.

61. Yao, Y., Yang, X., Shi, Z. and Ren., G. (2014). Anti-inflammatory activity of saponins from quinoa (chenopodium quinoa willd.) seeds in lipopolysaccharide-stimulated RAW 264.7 macrophages cells. Journal of Food Science, 79(5): 1021 - 1022.

62. Reddy, A. M., Lee, J. Y., Seo, J. H., Kim, B. H., Chung, E. Y., Ryu, S. Y., Kim, Y. S., Lee, C. K., Min, K. R. and Kim, Y. (2006). Artemisolide from Artemisia asiatica: nuclear factor-kappaB (NF-kappaB) inhibitor suppressing prostaglandin E2 and nitric oxide production in macrophages. Archives Pharmacal Research, 29: $591-597$.

63. Choi, Y., Lee, M. K., Lim, S. Y., Sung, S. H. and Kim, Y. C. (2009). Inhibition of inducible NO synthase, cyclooxygenase- 2 and interleukin-1beta by torilin is mediated by mitogen-activated protein kinases in microglial BV2 cells. British Journal of Pharmacology, 156: 933 - 940.

64. Kim, J. M., Lee, P., Son, D., Kim, H. and Kim, S. Y. (2003). Falcarindiol inhibits nitric oxidemediated neuronal death in lipopolysaccharide-treated organotypic hippocampal cultures. Neuroreport, 14: 1941 -1944. 
65. Kim, B. H., Hong, S. S., Kwon, S. W., Lee, H. Y., Sung, H., Lee, I. J., Hwang, B. Y., Song, S., Lee, C. K., Chung, D., Ahn, B., Nam, S. Y., Han, S. B. and Kim, Y. (2008). Diarctigenin, a lignan constituent from Arctium lappa, down-regulated zymosan-induced transcription of inflammatory genes through suppression of DNA binding ability of nuclear factor-kappaB in macrophages. Journal Pharmacology and Experimental Therapeutics, 327: 93 - 401. 